\title{
Cationic Crosslinked Nanocellulose-based Matrices for the Growth and Recovery of Intestinal Organoids
}

\author{
Rodrigo Curvello and Gil Garnier*
}

Bioresource Processing Research Institute of Australia (BioPRIA), Department of Chemical Engineering, Monash University, Australia

*E-mail: gil.garnier@monash.edu

$\underline{\text { Supplementary Information }}$ 
a

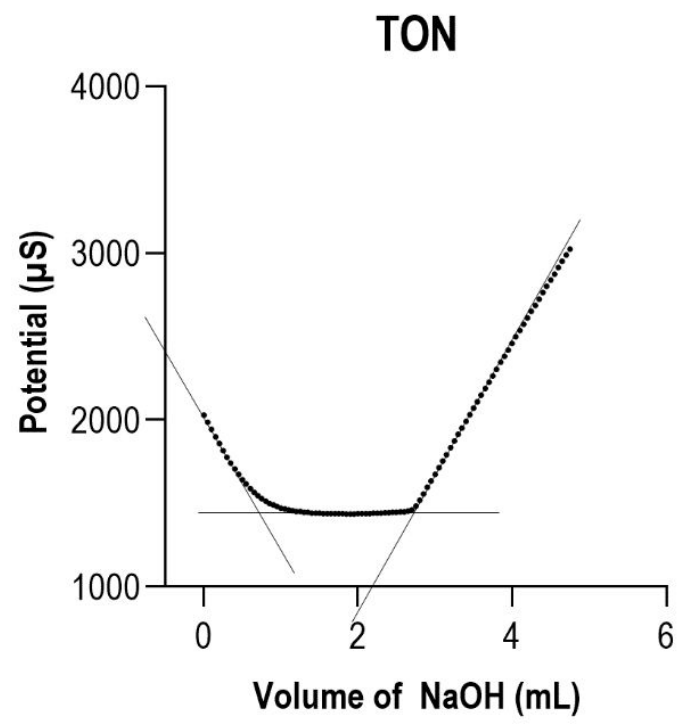

b

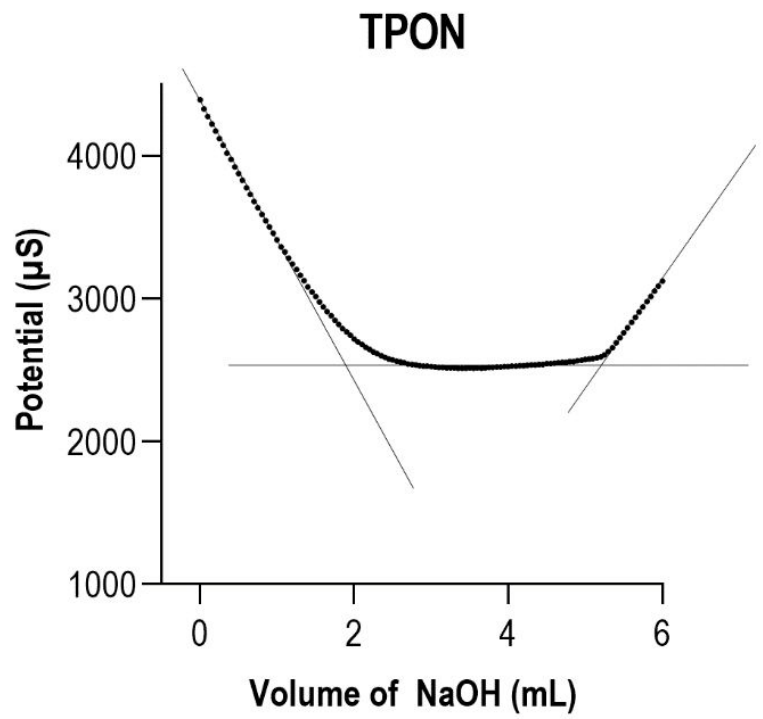

$$
C C=\frac{c\left(V_{2}-V_{1}\right)}{w}
$$

$$
\begin{aligned}
& C C=\frac{0.103(2.72-0.78)}{0.21} \\
& C C=\frac{0.951 \mathrm{mmol} \mathrm{COO}^{-}}{g \text { fibre }} \\
& \text { Average }=\frac{0.982 \pm 0.009 \mathrm{mmol} \mathrm{COO}^{-}}{\text {g fibre }}
\end{aligned}
$$

$$
C C=\frac{c\left(V_{2}-V_{1}\right)}{w}
$$

$$
\begin{gathered}
C C=\frac{0.103(5.73-1.93)}{0.20} \\
C C=\frac{1.957 \mathrm{mmol} \mathrm{COO}^{-}}{g \text { fibre }} \\
\text { Average }=\frac{\mathbf{1 . 9 2 6 \pm 0 . 0 3 4 \text { mmol Coo } ^ { - }}}{\text { g fibre }}
\end{gathered}
$$

Figure S1. Conductometric titration of (A) TON and (B) TPON fibres. Graphs are representative data of experiments performed in triplicates. 
a

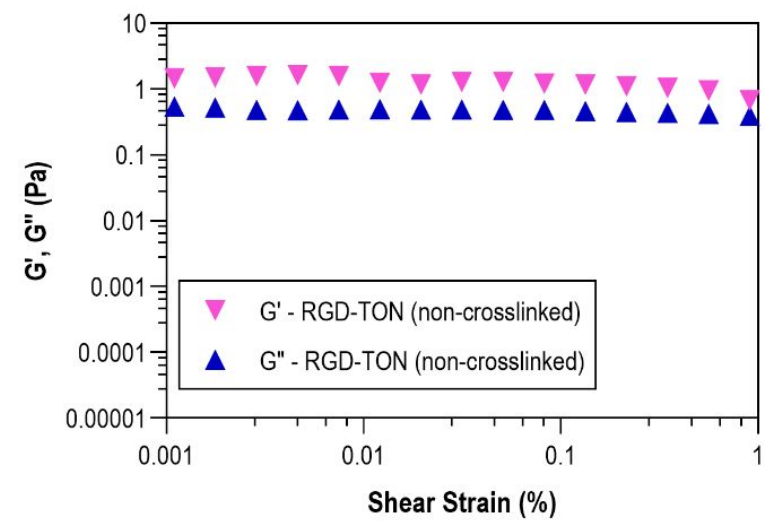

b

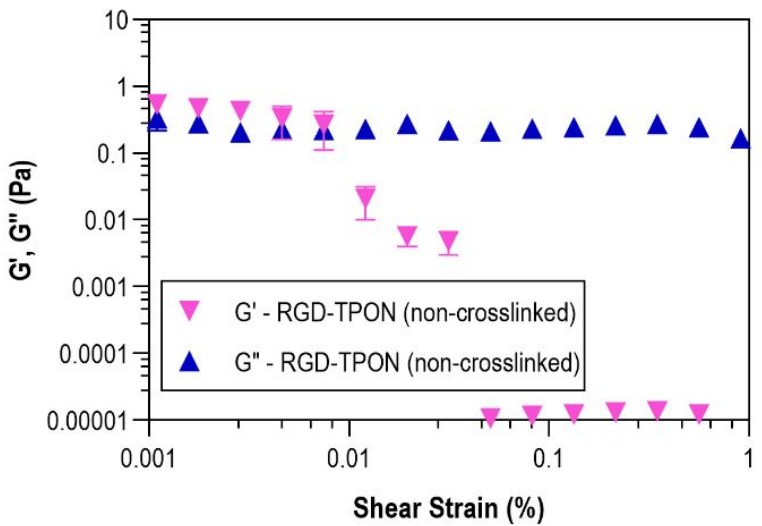

Figure S2. Storage (G') and loss modulus (G”) of non-crosslinked 0.1 wt.\% (A) RGD-TPON and (B) RGD-TON hydrogels.

a

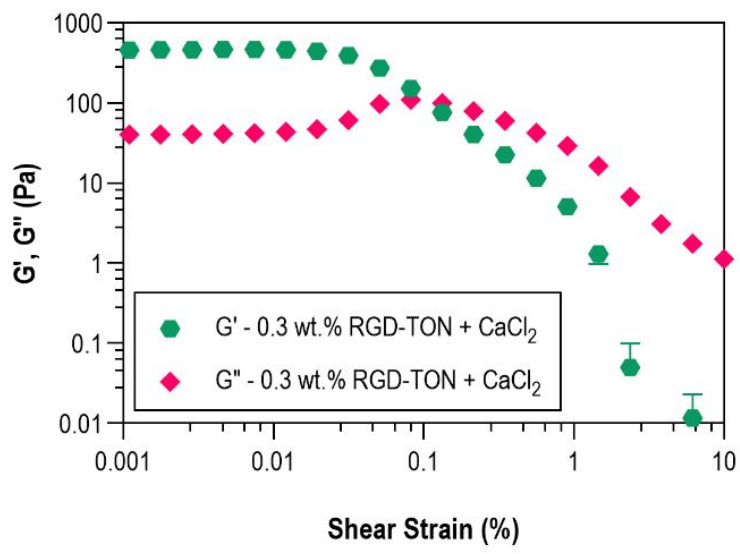

b

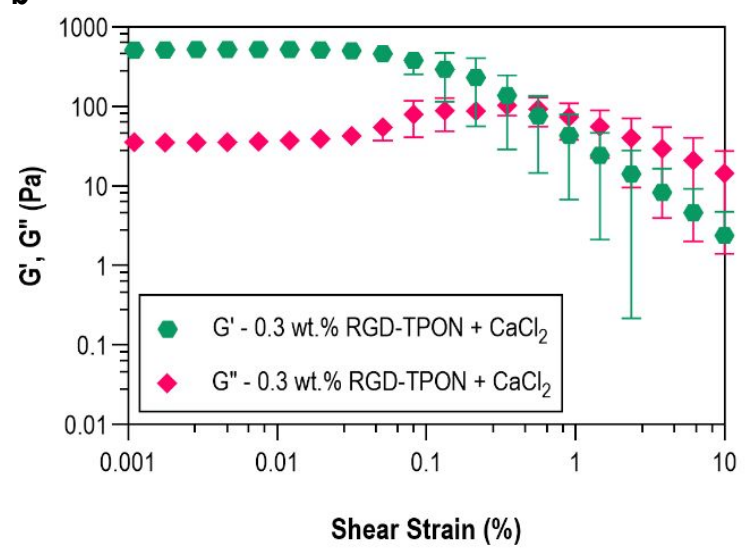

Figure S3. Storage (G') and loss modulus (G”) of 0.3 wt.\% (A) RGD-TPON and (B) RGD-TON hydrogels crosslinked with $\mathrm{CaCl}_{2}$.

Table S1. Crosslinking density for RGD-TON and RGD-TPON hydrogels crosslinked with $\mathrm{CaCl}_{2}(50$ $\mathrm{mM}$ )

\begin{tabular}{lc}
\hline Hydrogel & $\begin{array}{c}\text { Crosslinking Density } \\
\left(\mathbf{m m o l} / \mathbf{m}^{3}\right)\end{array}$ \\
\hline RGD-TON & $20.49 \pm 0.29$ \\
\hline RGD-TPON & $31.14 \pm 0.05$ \\
\hline
\end{tabular}


a

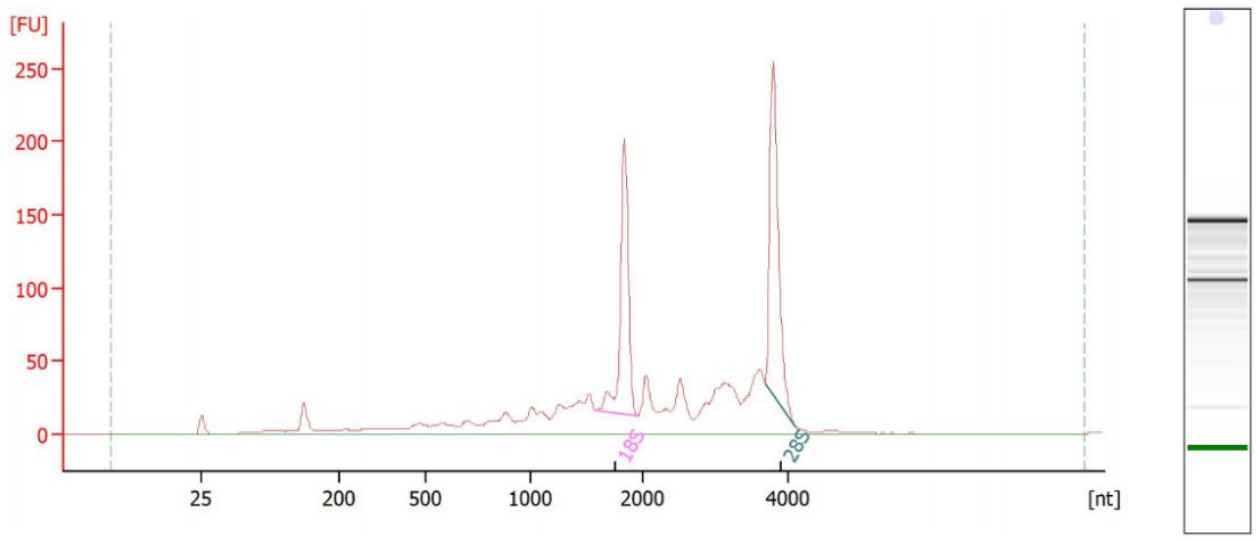

Overall Results for sample 1 : Matrigel

RNA Area: $\quad 1,228.1 \quad$ RNA Integrity Number (RIN): $\quad 7.6$ (B.02.10)

\section{b}
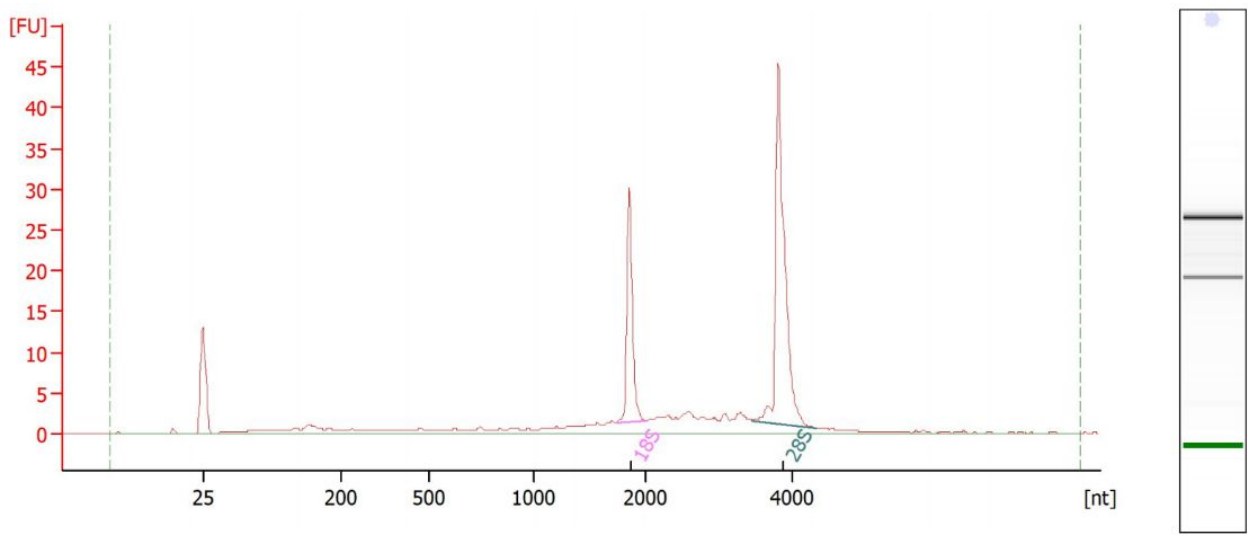

Overall Results for sample 2 : $\quad$ Hydrogel-Ca
RNA Area:
139.3
RNA Integrity Number (RIN):
$9($ B.02.10)

C

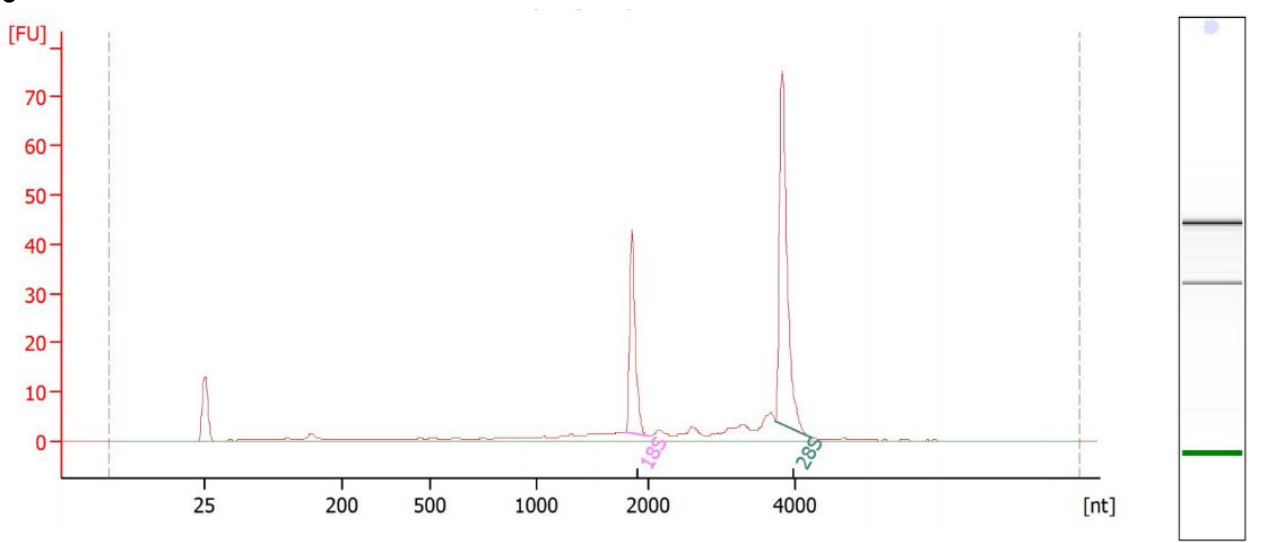

Overall Results for sample 3 : $\quad$ Hydrogel-Mg

$\begin{array}{llll}\text { RNA Area: } & 166.7 & \text { RNA Integrity Number (RIN): } & 9\end{array}$

Figure S4. Evaluation of RNA samples through a bioanalyzer. Eletropherogram and RNA integrity number (RNA) for RNA samples extracted from organoids grown in Matrigel and RGD-TPON hydrogels crosslinked with $\mathrm{CaCl}_{2}$ and $\mathrm{MgCl}_{2}$. 